\title{
Pendidikan Multikultural: Upaya Meminimalisir Konflik dalam Era Pluralitas Agama
}

\author{
Ruslan Ibrahim ${ }^{1}$
}

\begin{abstract}
Abstrak:
Problem utama kehidupan dalam era pluralitas agama adalah terjadinya konflik, baik antar individu maupun kelompok. Konflik bisa disebut sebagai entitas yang abadi dalam setiap perbedaan. Karena itu, menghilangkannya semasih ada perbedaan adalah "mustahil", tetapi yang bisa dilakukan adalah meminimalisir. Strateginya adalah penerapan pendidikan multikultural dalam kurikulum, selain adanya kesepakatan dialog dari kalangan yang berbeda. Namun, perlu ditegaskan bahwa sesuai dengan peran dan fungsi pokok pendidikan sebagai transfer nilai dan pengetahuan (transfer of values and knowledge), maka pendidikan multikultural merupakan jalan yang lebih signifikan dibanding dengan strategi lain, karena pendidikan multikultural memiliki cita-cita ideal, yaitu terwujudnya perdamaian, keadilan, dan persaudaraan sosial, anti konflik, kekerasan, dan diskriminatif.

Kata Kunci: Pluralitas Agama, Konflik dan Pendidikan Multikultural
\end{abstract}

\section{A. Pendahuluan}

Sejak jatuhnya Presiden Soeharto dari kekuasaannya, yang kemudian diikuti dengan masa yang disebut sebagai "era reformasi", kebudayaan Indonesia cenderung mengalami disintegrasi. Krisis

* Penulis adalah lulusan Jurusan Tarbiyah STAIN (sekarang IAIN Mataram). Menyelesaikan Program Magister Konsentrasi Pemikiran Pendidikan Islam di UIN Sunan Kalijaga Yogyakarta, dan pada tempat yang sama, sekarang sedang menempuh Program Doktor Studi Islam dengan spesifikasi Pemikiran Pendidikan Islam. 
moneter, ekonomi, politik, dan agama yang bermula sejak akhir 1997 mengakibatkan terjadinya krisis kultural di dalam kehidupan bangsa dan negara. Pada waktu itu pendidikan dijadikan sebagai alat politik untuk melanggengkan kekuasaan yang memonopoli sistem pendidikan untuk kelompok tertentu (Tilaar, 2004: 123). Dengan kata lain, pendidikan multikultural belum dianggap penting walaupun realitas kultural dan agama sangat beranekaragam.

Berbeda dengan era reformasi sekarang, walaupun pendidikan multikultural sebagai hal yang baru di tanah air, akhir-akhir ini sangat intensif dibicarakan dan didiskusikan oleh berbagai elemen, baik akademisi, LSM, dan organisasi kemasyarakatan. Hal ini menunjukkan bahwa dalam perkembangannya bangsa Indonesia yang memiliki keanekaragaman agama, budaya, suku, dan bahasa, tidak lagi membutuhkan konsep pendidikan monokultural-eksklusif dan diskriminatif (Bikhu Parekh 2002: 224-225). Sebagai bangsa yang memiliki kekayaan budaya, Indonesia sangat membutuhkan perdamaian, keadilan, persamaan, dan seterusnya yang merupakan unsur yang dapat dilahirkan oleh pendidikan multikultural. Tetapi, patut dicatat bahwa akhir-akhir ini yang terjadi justru jauh dari harapan kemanusiaan yang mengedepankan nilai-nilai keadilan sosial, keharmonisan, keamanan, perdamaian, dan persaudaraan. Dengan kata lain, diskriminasi, konflik sosial agama, krisis politik, ekonomi, budaya dan pendidikan, semakin menggurita di negeri ini. Salah satu persoalan penting yang perlu dipertanyakan adalah bagaimana solusi agar problem-problem tersebut dapat diminimalisir?.

Jika persoalan tersebut ditelaah menggunakan pendekatan antropologi sosial (social anthropology) (Achmad Fedyani Saifuddin, 2005: 414), maka tindakan anarkhis yang dilakukan oleh sekelompok masyarakat/orang tertentu atas yang lainnya tentu bertentangan dengan nilai-nilai kemanusiaan yang adil dan beradab, yang merupakan salah satu dari lima landasan dasar negara Indonesia (Pancasila). Selain bertentangan dengan Pancasila juga bertentangan dengan pluralitas agama dan budaya.

Apabila dikaji secara mendalam ajaran Islam, Islam sangat ramah dan menghargai keanekaragaman sebagai realitas (hukum alam). Dalam hal ini, konsep rahmatan lil'alamin merupakan landasan kultural ajaran Islam. Untuk menjalankan misi kemanusiaannya tersebut, Islam memiliki instrumen yaitu meletakkan pendidikan pada berisan terdepan, karena pendidikanlah yang secara langsung berhadapan dengan umat manusia (Abuddin Nata, 2001: 100). Dalam 
proses pendidikan ini terjadi transfer nilai dan pengetahuan dengan menghasilkan para peserta didik yang memiliki keimanan dan ketaqwaan serta ilmu pengetahuan. Konsep tersebut perlu dipahami secara terbuka terutama dalam era pluralitas agama seperti sekarang ini, agar tidak terkesan Islam sebagai agama ekslusif-diskriminatif terhadap manusia.

\section{B. Konsepsi tentang Pendidikan Multikultural}

Sebelum diuraikan tentang pendidikan multikultural secara keseluruhan dan komprehensif, terlebih dahulu penulis akan menguraikan tentang istilah multikultural dan hal-hal yang berhubungan dengannya agar terdapat pemahaman yang lebih mendalam tentang makna istilah tersebut. Secara kebetulan juga, istilah ini bagi masyarakat Indonesia sebagai hal yang baru.

Dalam konteks kehidupan yang multikultural, pemahaman yang berdimensi multikultural harus dihadirkan untuk memperluas wacana pemikiran keagamaan manusia yang selama ini masih mempertahankan "egosime" keagamaan dan kebudayaan. Haviland mengatakan bahwa multikultural dapat diartikan pula sebagai pluralitas kebudayaan dan agama. Dengan demikian, jika kebudayaan itu sudah plural, maka manusia dituntut untuk memelihara pluralitas agar terjadi kehidupan yang ramah dan penuh perdamaian. Pluralitas kebudayaan adalah interaksi sosial dan politik antara orang-orang yang berbeda cara hidup dan berpikirnya dalam suatu masyarakat. Secara ideal, pluralisme kebudayaan berarti penolakan terhadap kefanatikan, purbasangka, rasisme, tribalisme dan menerima secara inklusif keanekaragaman yang ada (William A. Haviland, terj. 1988: 289-290).

Sikap saling menerima, menghargai nilai, budaya, keyakinan yang berbeda tidak otomatis akan berkembang sendiri. Apalagi karena dalam diri seseorang ada kecenderungan untuk mengharapkan orang lain menjadi seperti dirinya. Sikap saling menerima dan menghargai akan cepat berkembang bila dilatihkan dan dididikkan pada generasi muda dalam sistem pendidikan nasional. Dengan pendidikan, sikap penghargaan terhadap perbedaan yang direncana baik, generasi muda dilatih dan disadarkan akan pentingnya penghargaan pada orang lain dan budaya lain bahkan melatihnya dalam hidup sehingga sewaktu mereka dewasa sudah mempunyai sikap itu (Paul Suparno, Kompas). Jika cita ideal pendidikan seperti itu dapat terwujud di hati sanubari dan prilaku masyarakat, maka itulah yang disebut dengan 
pendidikan multikultural yang bermuara pada multikulturalisme. Multikulturalisme adalah aspek yang tidak terbantahkan bagi seluruh masyarakat Indonesia, entah hal itu disadari atau tidak. Fay mengemukakan bahwa multikulturalisme menunjukkan suatu yang krusial dalam dunia kontemporer. Dalam dunia multikultural harus mementingkan adanya berbagai macam perbedaan antara yang satu dengan yang lainnya dan ada interaksi sosial di antara mereka. Para Multikulturalis menfokuskan pada pemahaman dan hidup bersama dalam konteks sosial budaya yang berbeda (Brian Fay, 1998: 3-4).

Multikulturalisme adalah respon terhadap realitas, dimana masyarakat selalu menjadi plural dan tidak monolitik. Keanekaragaman membawa perbedaan dan dapat berujung pada konflik. Namun, bukan berarti konflik selalu disebabkan oleh perbedaan. Dari sudut pandang agama, keragaman keyakinan, budaya, dan pandangan hidup penting untuk diangkat kembali mengingat penganut agamaagama di Indonesia masih awam, sehingga sangat rawan dengan konflik dan kekerasan.

Menurut Jandra, ada dua fakta yang perlu dikemukakan sehubungan dengan merebaknya konflik dalam masyarakat yang berlarut-larut. Pertama, dalam sejarahnya pertemuan agamaagama dan perbenturan kadang-kadang tidak terelakkan, karena masalah agama lebih sensitif dibanding dengan yang lainnya. Dalam hubungan antara Islam dengan agama lain, ajaran Islam dengan tegas mengatakan bahwa "bagimu agamamu dan bagiku agamaku" (al Kafirun: 6) dan pengakuan Nashrani dalam keputusan Vatikan II "gereja memandang umat Islam dengan penuh hormat". Kedua, bila diamati dalam kurun waktu tiga dekade di penghujung abad XX dan awal abad XXI, ada dua gejala sosial yang muncul ke permukaan, yaitu fenomena sosiokultural yang menggejala pada masyarakat postmodern (postmodernity), dan fenomena transmisi global seperangkat "kesadaran dan institusi" modern (sosial, ekonomi, dan budaya) hingga menyentuh masyarakat yang belum modern yang disebut juga "globalisasi" (M. Jandra, 2005: 232-233).

Multikulturalisme baik pada tingkat lokal, nasional, dan global pada umumnya mengedepankan prinsip keadilan dan persamaan. Untuk mewujudkan prinsip multikulturalisme tersebut, yang dibutuhkan sekarang bukan monokulturalisme, bukan pembauran tetapi pembaruan, bukan koeksistensi tetapi pro eksistensi, bukan ekslusi tetapi inklusi, dan bukan separasi tetapi interaksi (Daniel Sparringga, 2003). 
Sebagai konsekuensi logis dalam kehidupan di era plural, kenyataan multikulturalisme tidak dapat dihindarkan, karena itu pendidikan yang terkait dengan multikultural adalah keharusan. Pendidikan yang dimaksud dapat diuraikan dalam tiga sub-nilai sebagaimana konsep Lawrence (Larry May (ed) 2001: 19-20), yaitu pertama, penegasan identitas kultural seseorang. Identitas kultural seseorang merupakan entitas fundamental dalam kehidupannya, dan itulah yang membedakannya dengan orang-orang di luar dirinya. Walaupun sebagai entitas fundamental dalam kehidupan seseorang, identitas tidak seharusnya ekslusif dan tidak berinteraksi dengan identitas-identitas eksternal, melainkan menampakkan wajah yang mengedepankan nilai-nilai kemanusiaan yang adil dan beradab yang merupakan tujuan dari pendidikan multikultural.

Kedua, penghormatan dan keinginan untuk memahami dan belajar dari kebudayaan-kebudayaan selain kebudayaannya. Memahami kebudayaan sesama manusia merupakan aspek penting dalam kehidupan di era plural. Kebudayaan orang lain di luar diri dan kelompoknya harus dijadikan kawan dialogis untuk mengetahui kelebihan dan kebenaran yang hadir bersama budaya eksternal tersebut. Kelebihan dan kebenaran yang dibawa oleh budaya luar inilah yang membantu pengembangan budaya internal seseorang. Ketiga, perasaan senang dengan perbedaan kebudayaan itu sendiri. Perbedaan adalah rahmat yang diberikan Tuhan kepada umat manusia dengan tujuan berkompetisi meraih kebaikan. Untuk itu, perbedaan harus dihargai dan disenangi bukan dibenci dan dicaricari kesalahannya, sehingga melahirkan konflik horizontal sosial agama.

Dalam konteks kehidupan yang plural, Parekh mengklasifikasi lima model multikulturalisme (Azyumardi Azra, 2005), yang hemat penulis dapat menjadi acuan penyelenggaraan pendidikan di tanah air. Penyelenggara pendidikan dapat memilah dan memilih mana di antaranya yang tepat dan relevan untuk konteks Indonesia. Kelima model multikulturalisme yang dimaksud adalah: Pertama, "multikulturalisme isolasionis" yang mengacu kepada masyarakat dimana berbagai kelompok kultural menjalankan hidup secara otonom dan terlibat dalam interaksi yang hanya minimal satu sama lain. Contoh-contoh kelompok ini adalah seperti masyarakat yang ada pada sistem "milled" di Turki Usmani atau masyarakat Amish di A.S. Kelompok ini menerima keragaman, tetapi pada saat yang sama berusaha mempertahankan budaya mereka secara terpisah dari masyarakat lain pada umumnya. 
Kedua, "multikulturalisme akomodatif", yakni masyarakat plural yang memiliki kultur dominan yang membuat penyesuaian dan akomodasi-akomodasi tertentu bagi kebutuhan cultural kaum minoritas. Masyarakat multikultural akomodatif merumuskan dan menerapkan undang-undang, hukum, dan ketentuan-ketentuan yang sensitif secara kultural, dan memberikan kebebasan kepada kaum minoritas untuk mempertahankan dan mengembangkan kebudayaan mereka. Sebaliknya kaum minoritas tidak menentang kultur yang dominan. Kelompok ini dapat ditemukan di Inggris, Prancis, dan beberapa Negara Eropa lainnya.

Ketiga, "multikulturalisme otonomis" yakni masyarakat plural dimana kelompok-kelompok kultural utama berusaha mewujudkan kesetaraan (equality) dengan budaya dominant dan menginginkan kehidupan otonom dalam kerangka politik yang secara kolektif bisa diterima. Konsern pokok kelompok-kelompok kultural terakhir ini adalah untuk mempertahankan cara hidup mereka yang memiliki hak yang sama dengan kelompok dominan; mereka menantang kelompok kultural dominan dan berusaha menciptakan suatu masyarakat dimana semua kelompok bisa eksis sebagai mitra sejajar. Jenis kelompok ini didukung oleh kelompok Iuebecois di Kanada, dan kelompok-kelompok muslim imigran di Eropa, yang menuntut untu bisa menerapkan syari'ah, mendidik anak-anak mereka pada sekolah Islam dan sebagainya.

Keempat, "multikulturalisme kritikal" atau "interaktif", yakni masyarakat plural dimana kelompok-kelompok kultural tidak terlalu konsern dengan kehidupan kultural otonom, tetapi lebih menuntut penciptaan kultur kolektif yang mencerminkan dan menegaskan perspektif-perspektif distingtif mereka. Kelompok budaya dominan tentu saja cenderung menolak tuntutan ini, dan bahkan berusaha secara paksa untuk menerapkan budaya dominan mereka dengan mengorbankan budaya-budaya kelompok-kelompok minoritas. Karena itulah kelompok-kelompok minoritas menantang kelompok kultur dominan, baik secara intelektual maupun politis, dengan tujuan menciptakan iklim yang kondusif bagi penciptaan sebuah kultur kolektif baru yang egaliter secara genuine. Jenis kelomopk diperjuangkan oleh masyarakat kulit hitam di A.S, Inggris, dan lain-lain.

Kelima, "multikulturalisme kosmopolitan", yang berusaha menghapuskan batas-batas kultural sama sekali untuk menciptakan sebuah masyarakat di mana setiap individu tidak lagi terikat dan committed kepada budaya tertentu dan begitu juga sebaliknya, 
secara bebas terlibat di dalam eksperimen-eksperimen interkultural dan sekaligus mengembangkan kehidupan kultural masing-masing. Pendukung jenis ini biasanya intelektual diasporik dan intelektual liberal yang cenderung pada postmodernis.

Lima klasifikasi multikulturalisme di atas tidak semuanya cocok untuk konteks Indonesia. Yang perlu dilakukan oleh penyelenggara pendidikan adalah menyaring kira-kira multikulturalisme mana yang tepat atau paling tidak mendekati tujuan meminimalisir konflik horizontal. Karena ragam dan macam multikulturalisme itulah yang melahirkan pendidikan multikultural, yaitu pendidikan untuk/tentang keragaman kebudayaan dalam merespon perubahan demografis dan kultural lingkungan masyarakat tertentu atau bahkan dunia secara keseluruhan.

Banks mengatakan bahwa pendidikan multikultural merupakan suatu konsep yang menyatakan bahwa seluruh peserta didik tanpa memperhatikan dari kelompok mana mereka berasal, seperti gender, etnik, ras, budaya, kelas sosial, agama, dan lain-lain diharapkan dapat memperoleh pengalaman pendidikan yang sama di sekolah atau lembaga pendidikan (J. A. Banks, 1997: 26). Pendidikan multikultural juga dapat diartikan sebagai sebuah gerakan reformasi yang dirancang untuk menghasilkan sebuah transformasi di sekolah, sehingga peserta didik baik dari kelompok gender maupun dari kelompok budaya dan etnik yang berbeda akan mendapat kesempatan yang sama untuk menyelesaikan sekolah.

Pendidikan multikultural menganggap sekolah sebagai sebuah sistem sosial (school as a social system) yang terdiri dari bagian-bagian dan variabel-variabel yang saling terkait. Maka, untuk membentuk sekolah yang menjunjung tinggi persamaan kesempatan memperoleh pendidikan, seluruh komponen utama dari sekolah secara substantif harus diganti. Jika hanya salah satu variabel dari sekolah, seperti kurikulumnya saja yang diganti, maka hal itu tidak dapat menghasilkan pendidikan multikultural (J. A. Banks, 1997: 26). Suyata juga mengatakan bahwa untuk mencapai pendidikan multikultural dalam sistem persekolahan, sekolah tidak dapat dibangun berdasarkan budaya elit. Sekolah perlu mengubah strategi budaya dari elit ke mayoritas budaya rakyat yang sangat plural. Dengan strategi ini, mobilisasi, dukungan, dan keikutsertaan masyarakat secara luas dapat diwujudkan (Suyata, 2001: 21).

Tujuan utama pendidikan multikultural untuk mengubah seluruh lingkungan atau suasana pendidikan, sehingga dengan pendidikan multikultural dapat meningkatkan respek atau perhatian 
terhadap kelompok-kelompok budaya yang luas atau berbeda untuk mendapatkan pendidikan yang sama (James A. Banks, 1987: 2930). Pay mengatakan bahwa pendidikan multikultural merupakan tujuan utama dari pembelajaran seumur hidup (life long learning) (Young Pay, 1990: 109).

Masalah utama yang terkait dengan pendidikan multikultural adalah keadilan sosial, demokrasi, dan hak asasi manusia (H.A.R. Tilaar, 2003: 167). Ketiga aspek tersebut, walaupun terkait erat dengan aspek ekonomi, politik dan hukum, bukan berarti tidak ada hubungannya dengan pendidikan. Hemat penulis, justru pendidikan memiliki peran signifikan untuk mencetak manusia-manusia yang berkeadilan sosial, memiliki visi politik yang demokratis, dan menunjung tinggi hak dan martabat orang lain. Tidak mengherankan apabila pendidikan multikultural berkaitan dengan isu-isu politik, sosial, kultural, moral, edukasional dan agama (H.A.R. Tilaar, 2003: 168). Tanpa kajian bidang-bidang ini maka sulit untuk diperoleh suatu pengertian mengenai pendidikan multikultural.

\section{Meminimalisir Konflik dalam Era Pluralitas Agama}

Perlu ditegaskan bahwa pendidikan multikultural bukan satusatunya upaya yang harus dilakukan untuk meminimalisir konflik agama. Bahtiar Effendy mengemukakan bahwa selain melalui pendidikan, konflik dalam era pluralitas agama dapat dikurangi melalui pendekatan yang melibatkan elite agama untuk merumuskan posisi mereka dalam kehidupan sosial, ekonomi dan politik (Bahtiar Effendy, 2001: 52). Barangkali tidak ada perbedaan antara penulis dengan Bahtiar, namun perlu diingat bahwa pendidikan merupakan aspek yang paling berperan dibanding aspek-aspek lainnya. Karena pendidikan merupakan proses transformasi nilai dan pengetahuan yang secara langsung berhubungan dengan peserta didik (Ahmad Syafi'I Ma'arif, 2004). Terkait dengan hal tersebut, Amin Abdullah menawarkan model studi agama dalam era pluralitas untuk meminimalisir terjadinya konflik dengan mengkaji Islam tidak saja dari salah satu aspek, misalnya aspek antropologis apalagi teologis normatif, tetapi diperlukan aspek fenomenologis yang mencari hakikat atau esensi dari apa yang ada dibalik segala macam bentuk manifestasi agama dalam kehidupan manusia di muka bumi (Amin Abdullah, 1999: 26-7). Dengan ungkapan lain, dalam kajian Islam diperlukan pendekatan yang multidimensional. Pendekatan multidimensional yang merupakan agenda pendidikan multikultural 
dapat merupakan jalan alternatif untuk megurangi lahirnya prejudiceprejudice atau prasangka buruk yang memicu social conflict dalam era pluralitas agama (S. Nasution, 1994: 49-50).

Selain hal-hal tersebut di atas - kaitannya dengan pendidikan multikultural era pluralitas agama - perlunya dilakukan pengembangan desain kurikulum dan metode pendidikan agama yang mampu menumbuhkan sikap saling menghargai antar pemeluk agama dan kepercayaan. Menurut Azra, kurikulum pendidikan multikultural mestilah mencakup tema-tema mengenai toleransi; tema-tema mengenai perbedaan ethnokultural, dan agama; bahaya diskriminasi; penyelesaian atau resolusi konflik dan mediasi; hak asasi manusia (HAM); demokrasi dan pluralitas; kemanusiaan universal, dan tema-tema lain yang relevan dengan kontek pluralitas (Azyumardi Azra, 2005). Tema-tema tersebut sangat urgen untuk mengurangi ketegangan-ketegangan sosial keagamaan, terutama di tanah air sering terjadi konflik horizontal. Di sinilah pentingnya pendidikan agama lintas kepercayaan (inter-religious education) (Shalahuddin, 2005: 118) atau pendidikan multikultural.

Pendidikan multikultural adalah proses penanaman cara hidup menghormati, tulus, dan toleran terhadap keanekaragaman budaya yang hidup di tengah-tengah masyarakat plural. Dengan pendidikan multikultural, diharapkan adanya kekenyalan dan kelenturan mental bangsa menghadapi benturan konflik sosial, sehingga persatuan bangsa tidak mudah patah dan retak (Musa Asy'arie, Kompas, 2003).

Dalam konteks global dan nasional, yang dikenal dengan muatan yang sangat majemuk, maka pendidikan multikultural menjadi sangat strategis untuk dapat mengelola kemajemukan secara kreatif, sehingga konflik dan kekerasan sosial yang bernuansa agama yang muncul sebagai dampak dari transformasi dan reformasi sosial dapat dikelola secara cerdas dan menjadi bagian dari pencerahan kehidupan bangsa ke depan.

Pendidikan multikultural bukan untuk menghilangkan sama sekali terjadinya konflik dan kekerasan sosial - karena keduanya merupakan part of life - melainkan mengurangi (meminimalisir) ketegangan (tension) antar-kelompok yang berbeda (Abdullah, 2005: 11-19). Dengan pendidikan multikultural, masyarakat dapat memahami kehidupan yang serba kompleks seperti era sekarang. Menurut Parekh, gagasan tentang dialogical consensus termasuk dialog antar-budaya (intercultural dialogue) dapat diwujudkan bila didukung pendidikan multikultural yang memberikan pemahaman 
kepada masyarakat luas tentang makna kehidupan yang sesungguhnya (Parekh, 2002: 268). Pendidikan multikultural dengan muatan toleran, saling menghargai dan seterusnya, hemat penulis, perlu diwujudkan dalam rangka melahirkan multikulturalisme yang sebenarnya sehingga kekerasan sosial yang bernuansa agama, baik di tanah air maupun di dunia global dapat dikurangi. Dengan demikian, akan melahirkan kesalingpahaman antar berbagai budaya yang berbeda (understanding culture) (Kennedy, 1990: 15).

Untuk melahirkan kehidupan yang harmonis, toleran dan saling menghargai atas perbedaan masyarakat, pendidikan multikultural juga membutuhkan dialogical consensus yang memuat paling tidak tiga hal penting, yaitu negosiasi, kompromi, dan konsensus (M. Amin Abdullah, 2005). Implikasi positif dari ketiganya adalah lahirnya perasaan empati dan simpati terhadap sesama manusia tanpa membedakan gender, agama, hak minoritas dengan mayoritas. Semuanya harus dapat berekspresi sebagai wujud kehidupan masyarakat dan budaya yang multikultural dan multireligius. Dengan lain ungkapan, harus adanya equality dalam era multikultural. Jika tidak demikian, maka bukan hal yang mustahil terjadinya kekerasan dan konflik sosial yang bisa ditimbulkan oleh keanekaragaman budaya, agama, dan suku bangsa, baik pada level lokal, nasional, maupun global.

\section{Penutup}

Dimana ada perbedaan disitu ada konflik, hanya saja perbedaannya terletak pada tensi konfliknya apakah dalam skala besar atau kecil. Perbedaan antar individu saja dapat melahirkan konflik, apalagi perbedaan keyakinan agama sebagai kelompok sosial yang lebih besar. Karena itu, kecerdasan manusia sebagai individu atau kelompok sosial menguranginya merupakan harapan semua orang.

Terkait dengan hal tersebut, pendidikan multikultural memiliki peran untuk meminimalisir konflik sosial agama dalam era pluralitas, namun ia bukan satu-satunya solusi. Untuk itu, pendidikan multikultural harus menggandeng model-model lain yang dapat mendukung tercapainya cita-cita meminimalisir konflik. Dialogical consensus merupakan salah satu model yang dapat mendukung cita-cita tersebut. Perlu ditegaskan bahwa sesuai dengan peran dan fungsi pokok pendidikan sebagai transfer nilai dan pengetahuan, maka pendidikan multikultural merupakan jalan yang lebih 
signifikan dibanding dengan beberapa jalan lain di atas. Pendidikan multikultural memiliki cita-cita ideal, yaitu terwujudnya perdamaian, keadilan, dan persaudaraan sosial, anti konflik, kekerasan, dan diskriminatif.

Dalam konteks ke-Indonesia-an, sebagai hal yang baru, pendidikan multikultural perlu didiskusikan, dirancang, dan dimasukan dalam kurikulum pendidikan, agar relevan dengan situasi dan kondisi bangsa. Hal ini dimaksudkan untuk menghindari cangkokan model pendidikan multikultural gaya barat dan eropa, tetapi asli model Indonesia.*

\section{DAFTAR REFERENSI}

Abuddin Nata, Paradigma Pendidikan Islam (Jakarta: Grasindo, 2001).

Achmad Fedyani Saifuddin, Antropologi Kontemporer Suatu Pengantar Kritis Mengenai Paradigma (Jakarta: Kencana, 2005).

Ahmad Syafi'I Ma'arif "Pendidikan dan Peningkatan Kualitas Moral Bangsa", Makalah disampaikan dalam Pidato Ilmiah pada Dies Natalis XXXIX FIS UNY, 14 September 2004.

Amin Abdullah, "Kesadaran Multikultural: Sebuah Gerakan Interest Minimalization dalam Meredakan Konflik Sosial" dalam Ainul Yaqin, Pendidikan Multikultural; Cross-Cultural Understanding untuk Demokrasi dan Keadilan (Yogyakarta: Pilar Media, 2005).

Amin Abdullah, "Searching for a Model of Philosophy of Religious Education for Peace in Contemporary Multicultural Era" (Paper yang dipresentasikan dalam Seminar Internasional dengan thema Multicultural Education: Cross-Cultural Understanding for Democracy and Justice, yang diadakan oleh UIN Sunan Kalijaga di Hotel Sahid Yogyakarta, 27-28 Agustus 2005).

Amin Abdullah, Studi Agama: Normativitas atau Historisitas? (Yogyakarta: Pustaka Pelajar, 1999).

Azyumardi Azra "Identitas dan Krisis Budaya: Membangun Multikulturalisme Indonesia" dalam http://kongres.budpar. go.id, diambil tanggal 24 Mei 2005.

Bahtiar Effendy, Masyarakat Agama dan Pluralisme Keagamaan (Yogyakarta: Galang Press, 2001).

Bikhu Parekh, Rethinking Multiculturalism: Cultural Diversity and 
Political Theory (Cambridge: Harvard University Press, 2002). Brian Fay, Contemporary Philosophy of Social Science: A Multicultural Approach (Massachusetts: Blank Well Publishers Ltd, 1998).

Daniel Sparringga "Multikulturalisme dalam Multiperspektif di Indonesia" dalam Forum Rektor Simpul Jatim, Hidup Berbangsa Etika Multikultural (2003).

Deal \& Kennedy, Corporate Cultures: The Rites and Rituals of Corporate Life (New York: Addision-Wesley Publishing Company, Inc, 1990).

H.A.R. Tilaar, Kekuasaan dan Pendidikan (Magelang: Indonesia Tera, 2003).

H.A.R. Tilaar, Multikulturalisme Tantangan-tantangan Global Masa Depan dalam Transformasi Pendidikan Nasional (Jakarta: Grasindo, 2004).

I Gusti Ngurah Bagus "Hidup Bersama dan Etik Multikultural: Peluang dan Tantangannya dalam Hidup Berbangsa" dalam Forum Rektor Simpul Jatim, Hidup Berbangsa Etika Multikultural (2003).

J. A. Banks "Multicultural Education: characteristics and goals" dalam Banks \& Banks (eds.), Multicultural Education: Issues and Perspectives (New York: Allyn and Bacon, 1997).

James A. Banks, Teaching Strategies for Ethnic Studies (USA: Allyn and Bacon, Inc., 1987).

Lawrence Blum "Anti Rasisme, Multikulturalisme, dan Komunitas Antar Ras: Tiga Nilai yang Bersifat Mendidik bagi sebuah Masyarakat Multikultural" dalam Larry May (ed.), Etika Terapan 1 sebuah Pendekatan Multikultural (Yogyakarta: Tiara Wacana, 2001).

M. Jandra "Pluralisme Agama dan Multikulturalisme: Usaha Mencari Perekat Sosial" dalam Zakiyuddin Baidhawi \& M. Toyibi (ed.), Reinvensi Islam Multikultural (Surakarta: PSB-PS UMS, 2005).

Musa Asy'arie "Pendidikan Multikultural dan Konflik Bangsa" dalam Kompas, 2003.

Paul Suparno "Pendidikan Multikultural" dalam http:/ /www.kompas. com.

S. Nasution, Sosiologi Pendidikan (Jakarta: Bumi Aksara, 1994).

Shalahuddin "Humanisasi, Inklusifisasi Pendidikan Islam dalam Konteks Multikulturalisme" dalam Millah Jurnal Studi Agama, Vol. V Nomor 1 Agustus 2005. 
Suyata "Pendidikan Multikultural dan Reintegrasi Nasional: Implikasi Kebijakan" Pidato Pengukuhan Guru Besar (FIP-UNY: 2001). William A. Haviland, Antropologi 2, terj. (Jakarta: Erlangga, 1988). Young Pay, Cultural Foundations of Education (USA: Merril Publishing Company, 1990). 